Newfoundland and Labrador Studies

\title{
Raymond B. Blake and Melvin Baker. Where Once They Stood: Newfoundland's Rocky Road towards Confederation
}

\section{Rainer Baehre}

Volume 35, Number 1-2, 2020

URI: https://id.erudit.org/iderudit/1076771ar

DOI: https://doi.org/10.7202/1076771ar

See table of contents

Publisher(s)

Faculty of Arts, Memorial University

\section{ISSN}

1719-1726 (print)

1715-1430 (digital)

Explore this journal

Cite this review

Baehre, R. (2020). Review of [Raymond B. Blake and Melvin Baker. Where Once They Stood: Newfoundland's Rocky Road towards Confederation].

Newfoundland and Labrador Studies, 35(1-2), 141-146.

https://doi.org/10.7202/1076771ar viewed online.

https://apropos.erudit.org/en/users/policy-on-use/ 
Raymond B. Blake and Melvin Baker. Where Once They Stood: Newfoundland's Rocky Road towards Confederation. Regina: University of Regina Press, 2019. ISBN 978-0-889-77607-4

This important book is the first full-length study of Newfoundland and Labrador's gradual entry into Confederation. In taking a chronological view from the mid-nineteenth century to the narrow victory for Confederation in 1948, the authors examine internal and mainland overtures for the colony/dominion to join the mainland. Over seven well-researched and detailed chapters supported by in-depth archival documentation, historians Raymond Blake and Melvin Baker offer "a reinterpretation" (p.x) of the ebbs and flows of these overtures, providing a sophisticated and, on the whole, thorough analysis that addresses the roots of Newfoundland's support for and long-term resistance to Confederation. In the process, they remind us that Newfoundland alone among the other Canadian provinces relied on a public referendum to decide the outcome.

The core question raised by the authors is why the majority of Newfoundlanders remained so reluctant to join Canada for over 80 years, despite the best efforts of a persistent colonial minority as well as Canadian politicians to convince them to do otherwise. In large part, Blake and Baker counter what critics of the past have assumed, a historical myth that this reluctance of Newfoundlanders to join is attributable to the "ignorance and stupidity of voters" (p. xi). In contrast, Blake and Baker argue convincingly that the underlying motivation behind this narrative is far more complicated, and that throughout all these years Newfoundlanders consistently made "informed choices."

While in many respects the authors tread on familiar grounds, they nevertheless attempt to include in their analysis other actors besides familiar politicians: the largely unrecognized Newfoundlanders from different regions whose lives were shaped and reshaped by this political class under the Terms of Union, including women, Indigenous peoples, and hitherto mostly voiceless outport residents. Where Once They Stood, however, remains primarily a political account placed 
within the context of Newfoundland's socio-economic history. A salient introduction, "Newfoundland: A Place in Search of Security," captures the main theme and existing historiography and effectively presents the authors' overall approach, methodology, and interpretive framework to guide the reader.

The book then moves through readily recognizable political eras, beginning with the 1860 s when an almost serendipitous encounter brought Newfoundland delegates led by Premier Hugh William Hoyles to the Charlottetown and Quebec conferences, only to return and have their pro-Confederate vision soundly rejected in the 1869 election. A second chapter examines the last third of the nineteenth century, a time when "the nation turns inward," and discusses the efforts by various Newfoundland governments to develop the country's own "national policy" as they sought to address the French Shore issue, fishery disputes, railway construction, economic diversity, poverty, fiscal crisis, and a refusal by mercantile and sectarian interests, principally Irish Catholics, to unite with Canada. Yet during these decades periodic conversations took place between federal and Newfoundland officials to again test the waters. A third chapter discusses how between 1901 and 1927 Newfoundland, now a Dominion, began to expand outward in seeking foreign investors and opening up central and western Newfoundland after the closing of the French Shore. The resulting lumber boom led by two major British-controlled pulp and paper mills, growth in the fishery during wartime demand, and industrial and hydro development in the 1920s together brought comparative prosperity to the island, though not without large-scale financial borrowing. In siding with Quebec, Ottawa took a greater interest in Newfoundland because of the Labrador boundary dispute, as that sparsely populated region showed enormous promise for hydro and mining developments. In this chapter, the authors cover a range of political disputes and shenanigans and explain well why some Newfoundland politicians looked towards Canada while others, such as Richard Squires and William Coaker and their supporters, stayed antiConfederate and remained deeply distrustful of Canadian intentions. 
This distrust came, in part, because of the federal government's position on Labrador but also was a consequence of Ottawa's termination of ferry subsidies to the mainland after the Newfoundland railway was nationalized.

The last half of the book sets the stage for why the majority of Newfoundlanders finally changed their minds on the Confederation issue. Hit hard by the Great Depression, Newfoundland found itself virtually bankrupt, encountering political corruption and the decline of the salt fish trade, and amid "chaos" and "despair," only to be rescued by giving up its political independence and reverting to colonial status under an unelected Commission of Government. Chapter Four describes how the province adapted to these developments, and how it experienced social and economic reconstruction during World War II, principally with the building of British, American, and Canadian military bases and a growth in demand for its natural resources. Politicians, however, understood that this grace period would not last. Ideologically, as the authors point out, Newfoundlanders were also now made aware of a growing acceptance of state intervention in the economy, such as outlined in the UK's Beveridge Report, a counter to prevailing views on laissez-faire capitalism; this opened up a wider audience among political reformers for advancing the idea of the social welfare state.

The final two chapters detail how the experiences of the Depression and this ideological shift opened up a public discourse about the future of a post-war Newfoundland. The period of the National Convention and the two referendums revealed a growing acceptance of social citizenship within a social welfare state. The latter concept opened the door to Confederation and the promised infusion of capital through the issuance of unemployment insurance and other benefits that would come from the federal government, a prospect, as the authors note, that appealed especially to increasingly politicized women of the impoverished Newfoundland and Labrador outports. The book concludes with a look at regional voting patterns in Newfoundland and makes clear that the narrow pro-Confederate majority in the second 
referendum was dominated by voters from these small coastal settlements who looked to undo the control of the St. John's mercantile community and the long-dominant credit system. The last "thing" that many pro-Confederates wanted to see was a return to "responsible government" and the dreadful social conditions that had existed during the 1930s.

Less criticism than observation, there are some gaps and oversights in the authors' analysis. One notes that this study remains heavily weighted top down. While the authors make multiple efforts to include local issues and attitudes from the island's different regions, they tend still to reflect the political class's observations rather than find direct evidence from outport Newfoundlanders themselves. Also, sometimes broader historical context would have been useful in understanding the political debates in Newfoundland over imperial control of the fishery along the French and American shores that placed obstacles against realizing Newfoundland's national policy in the late nineteenth century; there is, for example, no mention of the Treaty of Washington of 1871, which came into effect in 1873 and opened Newfoundland's inshore fisheries to American schooners. In addition, there is no mention of Joey Smallwood in the 1920s as a labour organizer and newspaper publisher in the Corner Brook and Deer Lake areas. Yet these early roots later contributed to support for the Confederation cause on the west coast, especially as a result of his support by W.J. Lundrigan and his son; Arthur Lundrigan in the post-war era became one of Smallwood's key advisors, in favour of economic reform, diversity, and industrialization. These linkages may help to explain why sub-regions that include the Northern Peninsula and White Bay, where the Bowater's mill and Lundrigan and Son's extended their operations, provided among the highest levels of pro-Confederation support in Newfoundland. Finally, in terms of understanding changing cultural attitudes towards government economic intervention and the desirability of the social welfare state, the authors point to the Beveridge Report, but one wonders, in light of the growing American and Canadian presence on the island during 
World War II, whether Newfoundlanders also learned of North American initiatives such as the New Deal and the election of the CCF in Saskatchewan. Certainly, Smallwood would have been aware of such measures and how they might be applied in Newfoundland in order to avoid returning to "poverty and oppression." Perhaps these topics could provide direction for further research on how Confederation came about.

Overall, this substantive, well-researched, and accomplished book recognizes and reinforces the complexities of Newfoundland and Labrador's history. The authors' discussion of the province's relationship with Canada over a 100 -year period adds significantly to our overall understanding of this country's history and the distinctive and separate identity of Newfoundland and Labrador, as a province. Newfoundland's decision to join Confederation and the mainland continues to rankle the island's unforgiving arch-nationalists, who remain convinced that the final outcome, a political squeaker, came as a result of British and Canadian machinations, collusion, and even conspiracy, circumventing legitimate electoral sentiment and denying the province its true independence and control over its own resources. Blake and Baker lay such dubious claims to rest, citing Joey Smallwood, who once commented, "Newfoundland joined Canada mostly for Newfoundland's sake” (p. 16).

Rainer Baehre

Historical Studies, Grenfell Campus, Memorial University 